\title{
The quiet side of technology
}

How many people understand what the state does on our behalf in prisons, in conflicts such as that in Northern Ireland, or in the murky world of demonstrations, pickets and strikes? And how well aware are scientists and technologists of the uses to which the armed forces, the police and the prison service put science and technology in pursuit of domestic policies? There is general and widespread ignorance of these subjects, and so the appearance of The Technology of Political Control, by Carol Ackroyd, Karen Margolis, Jonathan Rosenhead and Tim Shallice (Penguin $£ 1.25$ ), should have been welcomed as a guide to an uncharted area. But the book, which stems from investigations organised by the British Society for Social Responsibility in Science (BSSRS), is too ill-focused, full of ideology and lacking in constructive thinking to have anything like a major impact on the scientist who knows little and wants to know more.

The authors themselves write that their approach 'may seem a curious amalgam of technological exposé and political analysis' and indeed it is. The first half of the book is devoted to a rambling analysis of the steps by which Britain could move towards being a 'Strong State', obsessed less with the threat from without than with that from within as it lays plans in anticipation of social conflict. Such a strong state would have learned a lot from the Northern Ireland experience and would practise the sort of low-intensity operations described by Frank Kitson in a book of that name. The army, more closely integrated with the police, would play a significant role in putting down insurgency.

If you believe, as do the authors, that the major function of the British legal system is to protect property, that the events of the twentieth century are increasingly posing the question of socialism or barbarism and that any new working class revolution will have to ensure that ultimate power resides with the working class, then you will probably accept their analysis. A less class-conscious view of the world would probably not reveal quite the same trends. but that is not the point. The point is, as the authors insist, that they are writing as concerned scientists and committed socialists'. The actual technology of political control is therefore at least as important.

The technology occupies the second half of the book and amongst other things includes phone-tapping, bugging, computers, sensing equipment, riot control techniques, method of psychological torture and misuse of psychiatry. It is described as a "vast and grim catalogue available to
Western governments'. But the detail contains few surprises. Indeed, it is one of the disappointments of the book that it draws so widely on newspaper cuttings and so little on detailed research by the authors. Given the grass roots contacts BSSRS has been developing in the past few years, such research surely ought not to have been impossible.

Take the example of the computer. The police and the army already use computers as data banks, of course, and these uses are described. It takes little imagination to spot that computers may have a broader role to play in stitching together low grade information: as one Pentagon enthusiast put it some years ago, given an adequate computer network in Northern Ireland, one could put all sorts of information together, such as that Mrs O'Reilly hasn't gone out for her daily walk to the baker's, and come up with suggestive patterns of use to the security forces. But if this is true and it has been done, it poses all sorts of questions about the privacy of the individual. The authors only very tangentially pick up this issue, either technically or in its implications, and give little sign of persistent enquiry. So it seems with many other technical issues.

To the authors of this book, modern technology in the service of the state's law enforcement agencies is clearly an affront because it is or will be used to keep down working-class-generated insurgency and revolution. But what do they say scientists should do? It is here that the book is at its weakest and briefest. The answer seems to be that they should work politically for the abolition of the capitalist state and the establishment of a workers' militia in place of the capitalist army.

Those who take a less extreme view will be more likely to say that many of the problems of technology and political control are not amenable to such neat solutions. In Northern Ireland there is now plenty of technology on both sides, none of it particularly palatable, and talk of workingclass control is meaningless. In other less strife-ridden parts of the country the unspectacular recipe is eternal vigilance. Technology does indeed have its role to play in law enforcement, and law enforcement agencies would be remiss if they did not use technology to the full. But the question is at what place use becomes abuse, reasonable enquiry becomes harassment, monitoring becomes intrusion. This can only be solved on a case-by-case basis, with at least some sort of trust in political institutions. The real need is for scientists who are involved in military and police research to be able to speak up when they see the balance shifting in an unsavoury direction. 